УДК 612.014+572.783

\author{
О. Р. Корженевська ${ }^{1}$, О. В. Севериновська ${ }^{2}$ \\ ${ }^{1}$ П’ятихатська загальноосвітня середня школа № 2 \\ ${ }^{2}$ Дніпропетровський національний університет ім. Олеся Гончара

\section{ОЦІНКА СТАНУ СЕРЦЕВО-СУДИННОЇ СИСТЕМИ МАШИНІСТІВ ЛОКОМОТИВІВ}

За допомогою методу добового моніторингу артеріального тиску оцінено стан серцевосудинної системи у машиністів П'ятихатського депо Придніпровської залізниці. Підвищення (на 1117 \%) артеріального тиску у машиністів 3 артеріальною гіпертензією I стадії під час добової робочої зміни пов'язане з недостатністю адаптації до фізичних і психоемоційних перенавантажень. Із поглибленням захворювання зміни тиску (особливо при роботі уночі) мають розрегульований характер, пов'язаний із структурними порушеннями мікарда лівого шлуночка.

$$
\begin{gathered}
\text { Е. Р. Корженевская }{ }^{1} \text {, Е. В. Севериновская }{ }^{2} \\
{ }^{1} \text { Пятихатская общеобразовательная средняя школа № } 2 \\
{ }^{2} \text { Днепропетровский наџиональный университет ил. Олеся Гончара } \\
\text { ОЦЕНКА СОСТОЯНИЯ СЕРДЕЧНО-СОСУДИСТОЙ СИСТЕМЫ } \\
\text { МАШИНИСТОВ ЛОКОМОТИВОВ }
\end{gathered}
$$

С помощыю метода суточного мониторинга артериального давления оценено состояние сердечнососудистой системы у машинистов Пятихатского депо Приднепровской железной дороги. Повышение (на 11-17 \%) артериального давления у машинистов с артериальной гипертензией I стадии во время суточной рабочей смены связано с недостаточной адаптацией к физическим и психоэмоциональным перегрузкам. С усугублением заболевания изменения давления (особенно при работе ночью) носят разрегулированный характер, связанный со структурными нарушениями миокарда левого желудочка.

$$
\begin{gathered}
\text { O. P. Korzhenevs’ka }{ }^{1} \text {, O. B. Severynovs'ka }{ }^{2} \\
{ }^{1} \text { Pjatykhatky General Education School № } 2 \\
{ }^{2} \text { Oles Honchar Dnipropetrovs'k National University } \\
\text { ESTIMATION OF THE CARDIOVASCULAR SYSTEM STATE } \\
\text { OF FOOT-PLATEMEN }
\end{gathered}
$$

With the help of daily monitoring of blood pressure we assessed the state of the cardiovascular system of foot-platemen of the Prydniprovsk railway Pjatykhatky Depot. Foot-platemen having the I stage of arterial hypertension demonstrated the 11-17 \% increase of arterial pressure during daily work. It is related to inefficient adaptation to the physical and psychoemotional overloads. With aggravation of the disease the change of arterial pressure during the work, especially night work, is misaligned and characterised by considerable structural abnormalities of the left ventricle myocardium.

\title{
Вступ
}

Сучасний рівень розвитку залізничного транспорту передбачає надзвичайне навантаження на людину. Аналіз критичних ситуацій свідчить, що 3 вини людини в 
системі «людина - середовище - об'єкт управління» виникає близько 70 \% технологічних аварій і катастроф. Тому досягнення оптимальної взаємодії людського чинника та навколишнього середовища є одним із головних завдань забезпечення безпеки руху на залізничному транспорті [2].

За останні роки робітники Укрзалізниці частіше хворіють і помирають від серцево-судинних розладів: 39,0 \% у 2010 році і 36,9 \% у 2011 році. Серед цих патологій переважає артеріальна гіпертензія $(46,2 \%)[1 ; 2]$. Частота артеріальної гіпертензії (АГ) в Україні становить $29,3 \%$ і зростає з кожним роком [12; 15]. 3 віком відбувається істотне збільшення частоти АГ. Ця патологія у людей віком понад 55 років перевищує $61 \%$ [11; 12]. Але останнім часом АГ все більше вражає молоді верстви населення та зумовлює підвищену захворюваність, інвалідність і смертність. Вона - один з основних чинників розвитку ішемічної хвороби серця та головна причина цереброваскулярних захворювань [9]. На сьогодні 20-25 \% населення України страждає на АГ. Смертність від серцево-судинних захворювань у загальній структурі смертності складає 53,5 \%, із них на ішемічну хворобу серця припадає 48,5 \% і на цереброваскулярні захворювання $35,2 \%$ [8; 10]. Інсульти серед населення України розвиваються учетверо частіше, ніж у країнах Західної Європи та США [4]. Лише 57 \% хворих на АГ проінформовані про наявність у них захворювання, лікуванням охоплено $17 \%$, а ефективна терапія проводиться лише 8 \% хворих.

У машиністів локомотивів установлено значний відсоток захворюваності на АГ i судинні дистонії. Це пов'язано 3 тим, що їх праця характеризується значним психоемоційним напруженням і здійснюється в умовах гіподинамії, впливу шуму, вібрації, електромагнітного поля та інших чинників виробничого середовища [10]. Несприятливі виробничі чинники в кабіні локомотива нерідко перевищують гігієнічні нормативи [7; 9]. Вивчаючи праці провідних лікарів вузлових лікарень Укрзалізниці [6], можна дійти висновку, що патогенний вплив виробничих і професійних чинників $\epsilon$ фактором ризику АГ, а потім і розладу серцево-судинної системи.

Вивчаючи стан хворих на серцеві розлади на вузловій станції Ковель Львівської залізниці, лікарі встановили, що близько 80 \% випадків серцево-судинних розладів зумовлює ішемічна хвороба серця [4]. Найбільше значення мають артеріальна гіпертензія, гіпертрофія міокарда, гіперхолестеринемія, дисфункція міокарда лівого шлуночка, порушення вегетативної регуляції серця [1; 2].

На Південній залізниці дослідження виявило, що для $20 \%$ осіб існує підвищений ризик раптової смерті, а 10-12 \% мають безсимптомні клінічні форми серцевосудинної патології. Схоже питання щодо РСС постало у вузловій залізничній лікарні міста П'ятихатки із сумною статистикою: за період з 2006 по 2010 рік померли від АГ три чоловіки та від ішемічної хвороби серця - один (машиністи електровозів).

Тому мета цієї роботи - з'ясувати вплив специфічних умов праці працівників рухомого складу Укрзалізниці на функціонування серцево-судинної системи.

\section{Матеріал і методи досліджень}

Обстежено 20 помічників машиністів (I група) та 20 машиністів (II група) з АГ віком 35-50 років. У дослідження включали робітників, які мали стаж роботи на залізничному транспорті 10-20 років. Групу порівняння (III група) склали 20 залізничників, які працюють в умовах залізничної галузі, але не мають артеріальної гіпертензії. Всі дослідження проведені на базі медичного пункту локомотивного депо та клінічного закладу «Залізнична вузлова лікарня» міста П’ятихатки. Усім проводили загальноклінічне обстеження стану серцево-судинної системи згідно із загальноприйнятими стан- 
дартними методами. Добовий моніторинг АТ здійснювався за допомогою амбулаторного монітора МДП-НС-01 (Росія) у режимі реального часу. АТ і частоту скорочень серця (ЧСС) визначали за стандартною програмою: вдень (з 6 до 22-ї год) через кожні 15 хв, вночі (з 22 до 6-ї год) - через кожні 30 хв до рейсу та після рейсу. Моніторинг уважали проведеним задовільно за наявності (після «вибракування» окремих досліджень) не менше 50 вимірювань на добу за умови наявності двох вимірювань упродовж однієї години та відсутності інтервалу між вимірюваннями понад годину.

Математичну обробку результатів моніторування проведено з використанням комп’ютерної програми для графічного їх виведення та розшифровування. Обчислювали такі показники: середні значення систолічного АТ (САT) та діастолічного АТ (ДАТ) за добу, активний (день) і пасивний (ніч) періоди, індекси часу - відсоток часу, протягом якого величини АТ перевищують критичний рівень (понад 140/90 вдень і 120/80 мм рт. ст. вночі), добовий індекс, що показує різницю між денним і нічним рівнем АТ, варіабельність АТ за стандартним відхиленням від середнього значення за денний і нічний періоди, величину ранкового підвищення АТ за різницею між максимальним і мінімальним АТ з 6 до 10 год.

Досліджували добовий профіль коливання артеріального тиску, для чого користувалися формулою: АТсер $=($ АТсист - АТдіаст $) / 3+$ АТдіаст.

Статистичну обробку результатів проведено з використанням програм Microsoft Office Excel та Origin 6.0 Professional. Для порівняння середніх значень використано $t$-критерій Стьюдента. Достовірною ввважали різницю при $p<0,05$.

\section{Результати та їх обговорення}

Детально проаналізувавши десятирічні звіти стану захворювання працівників П’ятихатського локомотивного депо при медичному пункті (шифр 9.0), з'ясували, що захворювання сердщево-судинної системи з 2007 р. почастішали удвічі. Це стосується і машиністів локомотивів, умови праці яких - цілодобова позмінна робота, високий рівень нервово-емоційної напруги, вібрація та шум.

Згідно з результатами обстеження, в усіх залізничників I-II груп діагностовано АГ I та II стадії. Причому 75 \% обстежених першої та 60 \% другої групи мали АГ I ступеня, 25 та 30 \% осіб першої та другої груп відповідно - II ступеня і у 10 \% машиністів локомотивів виявлено найтяжчий, III ступінь розвитку цієї вади серця. Такий розподіл досліджених залежно від умов праці та впливу факторів виробничого середовища вигідно відрізняється від аналогічного показника, що виявляється у популяційних дослідженнях [5]. Це можна пояснити ретельнішим відбором робітників комплексних бригад за результатами щоденних (для локомотивних бригад) і щорічних профілактичних оглядів. Результати добового моніторингу артеріального тиску III групи порівняння такі: вдень значення САТ/ДАТ - 140/90, уночі - 120/70 мм рт. ст. Ці дані збігаються із загальновідомими, а відмічені коливання пов'язані 3 добовим ритмом, фізичною активністю та психоемоційним станом людини $[2 ; 7 ; 10 ; 15 ; 16]$.

Як відмічають медичні працівники, у людей, які працюють у нічну зміну, коливання АТ протягом доби не тільки мають повільний і плавний двофазовий характер залежно від циркадного добового ритму, а й спостерігаються частіші коливання упродовж від декількох хвилин до години у різні періоди доби. Результати добового моніторингу основних показників серцево-судинної системи машиністів і помічників машиністів локомотивів свідчать, що середньодобові показники САТ та ДАТ у машиністів та їх помічників, хворих на АГ I і II стадії, дещо підвищилися під час рейсу порівняно зі значеннями до рейсу (табл. 1). 
Добовий профіль артеріального тиску в машиністів і помічників машиністів 3 артеріальною гіпертензією

\begin{tabular}{|l|c|c|c|c|}
\hline \multirow{2}{*}{\multicolumn{1}{|c|}{ Показники }} & \multicolumn{2}{|c|}{ Результати осіб з АГ І стадії } & \multicolumn{2}{c|}{ Результати осіб з АГ ІІ стадії } \\
\cline { 2 - 5 } & до рейсу & під час рейсу & до рейсу & під час рейсу \\
\hline Систолічний АТ сер., мм рт. ст. & $141,7 \pm 3,5$ & $153,2 \pm 2,9$ & $149,8 \pm 4,0$ & $161,6 \pm 3,7$ \\
\hline Діастолічний АТ сер., мм рт. ст. & $91,3 \pm 3,7$ & $108,2 \pm 2,5^{*}$ & $98,4 \pm 4,2$ & $111,0 \pm 3,5^{*}$ \\
\hline Систолічний АТ денний, мм рт. ст. & $144,7 \pm 2,2$ & $151,8 \pm 1,8$ & $157,6 \pm 5,5$ & $169,4 \pm 3,7$ \\
\hline Діастолічний АТ денний, мм рт. ст. & $99,3 \pm 1,6$ & $105,5 \pm 1,7$ & $95,2 \pm 3,0$ & $108,2 \pm 2,8$ \\
\hline Систолічний АТ нічний, мм рт. ст. & $144,2 \pm 3,8$ & $159,9 \pm 2,9$ & $142,3 \pm 4,5$ & $161,5 \pm 3,6$ \\
\hline Діастолічний АТ нічний, мм рт.ст. & $93,3 \pm 2,0$ & $99,5 \pm 1,3$ & $107,6 \pm 3,6$ & $113,3 \pm 4,0$ \\
\hline Індекс часу систолічного АТ денний, \% & $42,0 \pm 3,2$ & $51,4 \pm 2,7^{*}$ & $63,1 \pm 3,7$ & $79,8 \pm 2,3^{* *}$ \\
\hline Індекс часу діастолічного АТ денний, \% & $55,2 \pm 2,6$ & $67,4 \pm 2,7^{* *}$ & $71,9 \pm 4,6$ & $88,8 \pm 2,5^{* *}$ \\
\hline Індекс часу систолічного АТ нічний, \% & $65,8 \pm 1,9$ & $78,2 \pm 2,9^{* *}$ & $89,1 \pm 1,3$ & $82,9 \pm 4,0^{* *}$ \\
\hline Індекс часу діастолічного АТ нічний, \% & $75,7 \pm 2,0$ & $86,4 \pm 2,5^{* *}$ & $35,5 \pm 3,9$ & $47,8 \pm 4,2^{*}$ \\
\hline Добовий індекс систолічного АТ, мм рт. ст. & $10,8 \pm 0,8$ & $12,9 \pm 0,5^{*}$ & $8,7 \pm 0,9$ & $7,6 \pm 0,7$ \\
\hline Добовий індекс діастолічногоАТ, мм рт. ст. & $10,1 \pm 1,0$ & $9,5 \pm 0,7$ & $5,5 \pm 1,0$ & $6,2 \pm 0,8$ \\
\hline Варіабельність систолічного АТ денного, мм рт. ст. & $10,4 \pm 0,5$ & $16,2 \pm 1,5^{* *}$ & $8,9 \pm 0,6$ & $8,2 \pm 0,2$ \\
\hline Варіабельність діастолічного АТ денного, мм рт. ст. & $9,8 \pm 0,8$ & $13,7 \pm 0,7^{*}$ & $5,7 \pm 0,9$ & $6,1 \pm 0,5$ \\
\hline Варіабельність систолічного АТ нічного, мм рт.ст. & $9,3 \pm 0,6$ & $14,5 \pm 1,1^{* *}$ & $5,9 \pm 0,7$ & $5,9 \pm 0,5$ \\
\hline Варіабельність діастолічного АТ нічного, мм рт. ст. & $10,7 \pm 0,8$ & $12,2 \pm 0,6$ & $6,3 \pm 0,2$ & $5,8 \pm 0,7$ \\
\hline Ранкове підвищення систолічного АТ, мм рт. ст. & $18,8 \pm 1,9$ & $28,4 \pm 2,7 *$ & $10,9 \pm 0,6$ & $13,8 \pm 1,0^{*}$ \\
\hline Ранкове підвищення діастолічного АТ, мм рт. ст. & $16,6 \pm 1,8$ & $27,6 \pm 2,3^{* *}$ & $10,5 \pm 0,6$ & $11,8 \pm 1,0$ \\
\hline
\end{tabular}

Примітки: * - вірогідно відносно даних до рейсу, при $p<0,05, * *-$ вірогідно при $p<0,01$.

Причому якщо середньоденні показники близькі до середньодобових, то середньонічні показники САТ у них під час рейсу на 10 \% вищі порівняно з даними до рейсу. Відмітимо, що Е. Г. Даценко зі співавторами [5], визначивши циркадність ритму АТ у працівниць залізниці, зробили висновок, що в них майже втричі частіше спостерігаються патологічні гістограми добового профілю АТ. Автори статті рекомендують брати до уваги рівень АТ не тільки вдень, а й уночі, а у разі виявлення патологічних змін коригувати графік і умови праці.

Суттєвіші та різноспрямовані зміни роботи серцево-судинної системи відмічені у машиністів з АГ ІІ стадії під час рейсу. Для машиністів цієї групи встановлено «монотонний» характер коливань САТ і ДАТ, із достовірно більшим підвищенням ранкового САТ. Воно, очевидно, зумовлене значнішими структурними порушеннями міокарда лівого шлуночка в осіб цієї групи [3; 9; 15$]$. Дані добового моніторування АТ у машиністів, хворих на АГ, у групах залежно від ЧСС наведені в таблиці 2.

Показники добового моніторування АТ у хворих на АГ залежно від ЧСС

Таблиия 2

\begin{tabular}{|c|c|c|c|c|c|c|c|c|}
\hline \multirow{2}{*}{$\begin{array}{c}\text { ЧСС, } \\
\text { уд./хв }\end{array}$} & \multirow{2}{*}{ AT } & \multicolumn{3}{|c|}{ Середній АТ, мм рт. ст. } & \multicolumn{2}{|c|}{ Індекс часу, \% } & \multicolumn{2}{|c|}{ Добовий індекс, \% } \\
\hline & & добовий & денний & нічний & CAT & ДАТ & CAT & ДАТ \\
\hline$<60$ & CAT & $142 \pm 13,7$ & $194 \pm 14,8^{*}$ & $131 \pm 13,9$ & \multirow[b]{2}{*}{44,1} & \multirow{2}{*}{42,4} & \multirow{2}{*}{13,2} & \multirow[b]{2}{*}{12,5} \\
\hline$\leq 60$ & ДАТ & $80 \pm 7,2$ & $96 \pm 7,5$ & $66 \pm 8,1$ & & & & \\
\hline $61-80$ & CAT & $172 \pm 11,6^{*}$ & $196 \pm 12,3^{*}$ & $142 \pm 11,3^{*}$ & \multirow{2}{*}{74,5} & \multirow{2}{*}{67,1} & \multirow{2}{*}{16,2} & \multirow{2}{*}{17,3} \\
\hline $61-80$ & ДАТ & $92 \pm 9,1^{*}$ & $100 \pm 8,2 *$ & $84 \pm 10,5^{*}$ & & & & \\
\hline $81-100$ & CAT & $181 \pm 12,4^{*}$ & $204 \pm 10,5^{*}$ & $138 \pm 9,4^{*}$ & \multirow{2}{*}{100,1} & \multirow{2}{*}{100,1} & \multirow{2}{*}{8,4} & \multirow{2}{*}{9,2} \\
\hline $81-100$ & ДАТ & $103 \pm 10,4 *$ & $108 \pm 10,4 *$ & $74 \pm 10,1$ & & & & \\
\hline
\end{tabular}

Примітка: * - вірогідно відносно даних осіб контрольної групи при $p<0,05$. 
Значна варіабельність АТ у машиністів частіше співвідноситься з розвитком кризового перебігу артеріальної гіпертензії та супутньої ішемічної хвороби серця [5]. У залізничників, відповідно до переходу у групу з вищою ЧСС, відзначено зростання середніх добового, денного та нічного значень АТ. Недостатнє зниження нічного АТ в осіб із найвищими значеннями ЧСС свідчить про вищий ризик розвитку серцевосудинних ускладнень.

Проблема артеріальної гіпертензії у машиністів надзвичайно актуальна. За нашими спостереженнями, середній вік пацієнтів із гіпертонічною хворобою I ступеня становить 41,2 , II ступеня - 46,7 років. Звертаємо увагу на інертність медицини в запобіганні такому швидкому прогресуванню хвороби.

\section{Висновки}

У машиністів електровозів переважає початкова стадія артеріальної гіпертензії, однак має місце низка чинників виробничого процесу, які сприяють прогресуванню захворювання. Серед них - цілодобова позмінна робота, високий рівень нервовоемоційної напруги, вібрація та шум. У машиністів локомотивів під час рейсу достовірно підвищилися середньодобові показники ДАТ.

У машиністів 3 артеріальною гіпертензією I стадії індекс часу АТ вірогідно підвищений під час рейсу (як робота удень, так і вночі), що зумовлено недостатньою адаптацією осіб до фізичних і психоемоційних перенапружень.

У машиністів з артеріальною гіпертензією II стадії під час нічної зміни встановлено підвищення індексу часу, протягом якого величини діастолічного АТ перевищують критичний рівень на фоні незначного зниження індексу часу систолічного АT, що свідчить про розвиток напруженого стану серцево-судинної системи в осіб у цих умовах.

Вірогідно збільшена величина ранкового АТ у машиністів локомотивів з АГ I стадії під час рейсу; незначно підвищена величина ранкового підвищення діастолічного АТ на фоні вірогідного збільшення величини ранкового підвищення систолічного АТ у машиністів з артеріальною гіпертензією II стадії.

\section{Бібліографічні посилання}

1. Алидзе Д. Об основных профессиональных патологиях у рабочих железной дороги. - Баку : Медиа Сфера, 2010. - 216 c.

2. Аналіз стану здоров'я осіб, працюючих на посадах, пов'язаних з безпекою руху на залізничному транспорті, та заходи щодо поліпшення медичних аспектів професійного добору на Укрзалізниці / А. С. Диба, В. М. Остапчук, О. М. Тубольцев, Г. І. Кочуєв // Медицина залізн. трансп. України. - 2002. - № 1. - С. 18-20.

3. Даценко Е. Г. Частота сердечных сокращений как фактор, влияющий на развитие и течение артериальной гипертензии / Е. Г. Даценко, Н. И. Яблучанский // Укр. терапевт. журн. - 2002. № 1. - C. 5-10.

4. Жолоб В. М. Распространение артериальной гипертензии у машинистов в связи с факторами риска // Одес. мед. журн. - 1999. - № 1. - С. 34-37.

5. Жолоб А. В. Динаміка показників добового моніторування артеріального тиску у машиністів локомотивів, котрі хворіють на артеріальну гіпертензію / А. В. Жолоб, Є. З. Доскач, В. М. Жолоб // Медицина залізн. трансп. України. - 2002. - № 1. - С. 39-42.

6. Івер В. В. Структура і динаміка первинної інвалідності на Придніпровській залізниці у 19922001 роках / В. В. Івер, В. П. Малий, Л. В. Шумакова // Медицина залізн. трансп. України. 2003. - № 1. - C. 9-10. 
7. Капцов В. А. Основные факторы профессионального риска у работников железнодорожного транспорта / В. А. Капцов, В. Б. Панкова, В. С. Кутовой // Гигиена и санитария. - 2001. № 1. - C 38-43.

8. Кобалава Ж. Д. Артериальная гипертония. - М. : Медгиз, 2001. - 210 с.

9. Коваль С. Н. Современные подходы к лечению больных с артериальной гипертензией // Укр. терапевт. журн. - 2001. - № 4. - С. 64-72.

10. Особливості перебігу артеріальної гіпертензії у працівників локомотивних бригад: Вплив виробничих чинників, якість життя, лікування, профілактичні заходи / Ф. А. Звершхановський, О. Б. Праць, В. М. Жолоб, С. З. Доскач // Медицина залізн. трансп. України. - 2004. № 1. - С. 81-85.

11. Тубольцев О. М. Епідеміологія і медико-соціальна значущість артеріальної гіпертензії у робітників залізничного транспорту / О. М. Тубольцев, О. М. Люлько, О. В. Кривоший. - Харків : Інф.-видавн. центр ГНА України, 2003. - 153 с.

12. Чепелевська Л. А. Соціально-гігієнічна оцінка сучасної медико-демографічної ситуації в Україні / Л. А. Чепелевська, О. П. Рудницький // Охорона здоров’я України. - 2010. - № 2. C. $72-77$.

13. Atrial dyssynchrony syndrome: An overlooked phenomenon and a potential cfuse of "diastolic" heart failure // J. C. Eicher, G. Laurent, O. Barthez et al. // Eur. J. Heart Fail. - 2012. - Vol. 59, N 3. P. 564-571.

14. Capillary filtration is reduced in lungs adapted to chronic heart failure: Morphological and haemodynamic correlates / W. Huang, M. P. Kingsbur, M. A. Turner et al. // Cardiovasc. Res. 2001. - Vol. 49. - P. 207-217.

15. Diurnal variation in incidence of stroke: Oxfordshire community stroke project / S. J. Wroe, P. Sandercock, J. Bamford et al. // Brit. Med. J. - 2009. - Vol. 304. - P. 155-157.

16. Franklin S. S. Significance of write-coat hypertension in older persons with isolated systolic hypertension: A metal-analysis using the International Database on Ambulatory Blood Pressure Monitoring in Relation to Cardiovascular Outcomes Population // S. S. Franklin, L. Thijs, T. W. Hansen // Hypertension. - 2012. - Vol. 59, N 2. - P. 198-204.

17. Upper normal blood pressures predict incident atrial fibrillation in healthy middle-aged men: A 35-year follow-up study / I. Grundvold, P. T. Skretteberg, L. K. Liest et al. // Hypertension. 2012. - Vol. 59, N 2. - P. 198-204.

Надійшла до редколегіï 16.05.2012 